AperTO - Archivio Istituzionale Open Access dell'Università di Torino

\title{
Glue barriers reduce earwig damage on apricots in north-western Italy
}

\section{This is the author's manuscript}

Original Citation:

Availability:

This version is available http://hdl.handle.net/2318/1642812

since 2020-04-06T19:59:26Z

Published version:

DOI:10.1080/09670874.2016.1178823

Terms of use:

Open Access

Anyone can freely access the full text of works made available as "Open Access". Works made available under a Creative Commons license can be used according to the terms and conditions of said license. Use of all other works requires consent of the right holder (author or publisher) if not exempted from copyright protection by the applicable law. 
This is the author's final version of the contribution published as:

Saladini, Matteo Alessandro; Asteggiano, Laura; Pansa, Marco Giuseppe; Giordani, Luca; Serre, Luca; Vittone, Graziano; Tavella, Luciana; Tedeschi, Rosemarie. Glue barriers reduce earwig damage on apricots in north-western Italy. INTERNATIONAL JOURNAL OF PEST MANAGEMENT. 62 (3) pp: 214-221.

DOI: $10.1080 / 09670874.2016 .1178823$

The publisher's version is available at:

http://www.tandfonline.com/doi/pdf/10.1080/09670874.2016.1178823

When citing, please refer to the published version.

Link to this full text:

http://hdl.handle.net/2318/1642812 
1 Title: Glue barriers reduce earwig damage on apricots in northwestern Italy

2

3 Matteo Alessandro Saladini ${ }^{\mathrm{a}}$, Laura Asteggiano ${ }^{\mathrm{b}}$, , Marco Giuseppe Pansa $^{\mathrm{a}}$, Luca Giordani ${ }^{\mathrm{b}}$, Luca

4 Serre $^{\mathrm{b}}$, Graziano Vittone $^{\mathrm{b}}$, Luciana Tavella $^{\mathrm{a}}$, Rosemarie Tedeschi $^{\mathrm{a}}{ }^{*}$
6

${ }^{a}$ Dipartimento di Scienze Agrarie, Forestali e Alimentari (DISAFA), ULF Entomologia Generale e Applicata, University of Torino, largo Paolo Braccini 2, I-10095 Grugliasco (TO), Italy

${ }^{\mathrm{b}}$ Consorzio di Ricerca Sperimentazione e Divulgazione per l'Ortofrutticoltura piemontese (CReSO), via Falicetto 24, I-12030 Manta (CN), Italy

${ }^{\mathrm{c} C u r r e n t}$ address: Tree Fruit Research and Extension Centre (TFREC), Washington State University, $1100 \mathrm{~N}$ Western Ave, Wenatchee WA 98801

*Corresponding author, e-mail rosemarie.tedeschi@ unito.it, phone number +390116708675.

\section{Abstract}

The European earwig, Forficula auricularia L. (Dermaptera: Forficulidae), is a well-known species that is cosmopolitan and present throughout Europe. Due to its omnivorous feeding behaviour, this species can act as a generalist predator, preying on several top fruit pests, but also as a pest causing shallow gouges or holes in soft fruits such as apricots, strawberries, raspberries or blackberries. In Piedmont (NW Italy), significant fruit damage has been observed lately in apricot orchards where earwigs fed on ripening fruits and made a considerable part of the produce unmarketable. In this study, we sampled earwig populations in three apricot orchards in Piedmont and tested the effectiveness of glue barriers applied to the tree trunks in reducing both earwig density in the canopy and fruit damage. The arboreal glues Rampastop ${ }^{\circledR}$ and Vebicolla ${ }^{\circledR}$ were tested both in the 5 field and laboratory trials. Glue barriers demonstrated to be effective control measures, significantly reducing earwig abundance in the canopy and fruit damage. Rampastop ${ }^{\circledR}$ gave better results on old 
trees with a very rough and cracked bark, since in that case Vebicolla ${ }^{\circledR}$ could not perfectly bond with the trunk.

\section{Keywords}

Forficula auricularia, Prunus armeniaca, arboreal glue, corrugated cardboard, orchards

\section{Introduction}

The European earwig, Forficula auricularia L. (Dermaptera: Forficulidae), is a well-known cosmopolitan species. Native to Europe, it has spread all over the world since the beginning of the $20^{\text {th }}$ century (Moerkens et al. 2011). Forficula auricularia is omnivore and feeds on a variety of plant materials, mosses, fungi, and small arthropods. In tree fruit crops, it is often considered as a potential biological control agent (Logan et al. 2007, Maher \& Logan 2007, Peusens \& Gobin 2008, Romeu-Dalmau et al. 2012) because it is an important predator of several fruit pests such as aphids, psyllids, scale insects, lepidopteran eggs and larvae and spider mites (Gobin et al. 2008). It was reported to prey on apple aphid Aphis pomi DeGeer, woolly apple aphid Eriosoma lanigerum (Hausmann) (Mueller et al. 1988, Nicholas et al. 2005), rosy apple aphid Dysaphis plantaginea (Passerini) (Dib et al. 2010, 2011), codling moth Cydia pomonella (L.) (Glenn 1977), pear psyllid Cacopsylla pyri (L.) (Sauphanor et al. 1994), leafroller Epiphyas postvittana (Walker) (Moerkens et al. 2009, Suckling et al. 2006), and different citrus aphids (Romeu-Dalmau et al. 2012).

However, feeding on buds, flowers, fruits and leaves, the European earwig can also cause direct plant damage, reduced crop yields and aesthetic injuries (Alston \& Tebeau 2011). In citrus groves, it is a foe for flowers and developing fruits (Kallsen 2006, Romeu-Dalmau et al. 2012). In grapes, berry contamination with earwig faeces, berry erosion and transfer of pathogens, with a subsequent deterioration of grape quality, were observed in several viticultural areas in Germany (Huth et al. 2011). Fruit damage is particularly relevant on soft fruits such as peaches, nectarines, apricots, cherries, strawberries, raspberries and blackberries, where the European earwig feeds on ripening 
53 fruits and may cause shallow gouges or holes that extend deeply into the fruit (Asteggiano \&

54 Vittone 2013, Caroli et al. 1993, Flint 2012, Lordan et al. 2014, Pollini 2010, Santini \& Caroli 1992). The incidence and severity of earwig outbreaks in soft fruit orchards have recently increased (Asteggiano \& Vittone 2013, Lordan et al. 2014, Pollini 2010), probably due to advances in integrated pest management (IPM) techniques and consequent reduction in use of broad-spectrum insecticides for control of common agricultural pests (Kallsen 2006, Logan et al. 2011).

In Piedmont (NW Italy), fruit growers have recently reported an increased fruit damage in apricot orchards, where earwigs feed on ripening fruits and make unmarketable a high percentage of the production (Vittone G., personal communication). To confirm earwigs as responsible for the damage, apricot branches bearing healthy fruits were isolated in white polythene net cages, and in half of the cages 10 earwigs per cage were introduced and kept for a week. After insect removal, fruit damage was observed only in the cages where earwigs were inserted, while no damage was observed in the controls (unpublished data).

Earwig control by means of insecticides is extremely hard to achieve and presents important challenges. Spraying as soon as earwigs migrate to the trees has little effectiveness because, although they are univoltine, their migration to the trees is not simultaneous. Insecticides with a long-lasting persistence would be required, but they are not consistent with IPM principles. On the other hand, spraying close to harvest time would make the product unsuitable for the market due to possible presence of agrochemical residues. It is therefore crucial increasing the knowledge on earwig presence and abundance in apricot orchards, and testing control strategies with low environmental impact that might be adopted also in organic fruit production. To this end, we sampled earwig populations in apricot orchards in Piedmont and compared two arboreal glues applied on the trunk as a mean to prevent earwigs from reaching and damaging fruits.

\subsection{Field trials}


Earwig populations were sampled in three commercial apricot orchards located in Costigliole Saluzzo, Piedmont, NW Italy in 2010 and 2011. In orchard 1 [UTM WGS84 4934460N 379094E; $545 \mathrm{~m}$ above sea level (a.s.1.), 0.163 ha], 'Pinckot' apricot trees were planted in 2006 with spacing of $4.0 \times 3.6 \mathrm{~m}$. In orchard 2 (UTM WGS84 4934461N 379703E; $528 \mathrm{~m}$ a.s.1., 0.158 ha), 'Tonda di Costigliole' apricot trees were planted in 1999 with spacing of $4.5 \times 3.5 \mathrm{~m}$. Orchard 2 was uprooted by the grower in the fall of 2010, and in 2011 it was replaced with orchard 3 (UTM WGS84 4935557N 380196E; 456 m a.s.1., 0.346 ha), an apricot orchard with trees of cv Pinckot planted with spacing of $4.3 \times 3.5 \mathrm{~m}$ in 2005 . In all orchards, weeds were chemically controlled only under the trees, making soil tillage unnecessary. Pest control consisted of one etofenprox treatment and one imidacloprid or acetamiprid treatment at the petal fall/fruit set stage, in the first half of April. Since earwigs are nocturnal and readily hide in shelters during daytime, population density was monitored in each orchard by means of corrugated cardboard strips $(20 \times 50 \mathrm{~cm})$ as used by Helsen et al. (1998), Burnip et al. (2002), and Nicholas et al. (2005). Cardboard strips were placed on the lower part of the trunk (approximately $30 \mathrm{~cm}$ above the ground) of five randomly selected trees, one strip per tree, on March 30 in 2010 and on April 4 in 2011, and checked weekly for presence of earwigs until the end of harvesting (July 8 in 2010 and June 20 in 2011). During field surveys, cardboard strips were replaced, and hidden individuals were collected with the help of a portable vacuum cleaner. All collected individuals were preserved in $70 \%$ ethanol and transferred to the laboratory for subsequent identification following description by Fontana et al. (2002).

In surveyed apricot orchards, we assessed the effectiveness of two arboreal glues in preventing earwigs from climbing up toward tree canopy. In each orchard, three plots were marked out to compare paste glue Rampastop $^{\circledR}$ (Protecta s.a.s., Le Thor, France; treatment 1), liquid glue Vebicolla $^{\circledR}$ [Vebi Istituto Biochimico s.r.l., S. Eufemia di Borgoricco (PD), Italy; treatment 2], and control (treatment 3). In the plots, treatments were randomly assigned and five trees per treatment were randomly chosen within each plot for observation. Glues were applied at the end of April, when the first earwigs were observed in the cardboard traps on control trees. No further glue 
application was made. Glues were applied on the lower part of the trunk (approximately $30 \mathrm{~cm}$ above the ground) of all trees in each plot: Vebicolla ${ }^{\circledR}$ was applied on plastic tape previously wrapped around the tree trunk, while Rampastop ${ }^{\circledR}$ was spread directly on the trunk. Rampastop ${ }^{\circledR}$ was applied also on neighbouring plants and on orchard stakes in all plots to prevent earwigs from reaching the plants by climbing up on the stakes. Earwigs trapped in the glues were counted weekly and removed with a small spatula, preserved in $70 \%$ ethanol, and subsequently identified to species level in the laboratory. In addition, in 2011 a corrugated cardboard strip $(20 \times 50 \mathrm{~cm})$ was placed above the glue on the trunk of all treated trees in order to assess earwigs' capability to bypass the glues. These strips were placed on May 24, and checked weekly for the presence of earwigs as described above. At harvest, all fruits of sampled trees were checked for damage by earwigs, and the number of damaged fruits was recorded. In 2010, harvest started on June 29 and July 16, and finished on July 7 and July 26 (four picks) in orchard 1 and orchard 2, respectively. In 2011, harvest started on June 4 and finished on June 20 (six picks) in both orchards 1 and 3. Data on local weather conditions during field experiments were provided by Rete Agrometeorologica, Regione Piemonte, Settore Fitosanitario (Torino, Italy).

\subsection{Laboratory trials}

In September, male and female earwigs were collected in IPM apricot orchards, and transferred to the laboratory in a large container before they were used in the experiments. Cardboard boxes $(50 \times 40 \times 25 \mathrm{~cm})$ were prepared as test units by standing a piece of apricot tree trunk (approximately diameter $10 \mathrm{~cm}$, length $30 \mathrm{~cm}$ ) in the box, on top of which a ripe apricot was laid. Three treatments were included: paste glue Rampastop ${ }^{\circledR}$, liquid glue Vebicolla ${ }^{\circledR}$, and control, with four replicates per treatment. Rampastop ${ }^{\circledR}$ and Vebicolla ${ }^{\circledR}$ glues were applied on the trunks following the same methodology used in field trials. Five randomly chosen earwigs were introduced per test unit, and cardboard boxes were subsequently sealed with masking tape in order to avoid insect escape. The use of sealed cardboard boxes allowed darkness conditions to encourage earwig 
activity. Percentage of damaged fruits, and for treated units number of insects trapped in the glue

131 were recorded 24 and 48 hours after earwig introduction.

\subsection{Statistical analysis}

133 Numbers of earwigs captured in cardboard strips placed above the glues and on control trees were 134 compared using the non-parametric analysis of Kruskal-Wallis as the assumption of normality and 135 homogeneity were not met (Shapiro-Wilk test and Levene test); the means were then separated 136 using Mann-Whitney $U$-test $(\mathrm{P}<0.05)$. Data on fruit damage were analysed by a generalized linear 137 model with a binary distribution and logit link, considering a randomised block design where each 138 fruit was a statistical unit; the blocks were represented by the two orchards. In the model the fixed 139 effects were glue (treatment), year and block, and the interaction glue * year. In case of significant 140 differences, means were separated through Bonferroni test $(\mathrm{P}<0.05)$.

141 In the laboratory trials, after checking normality and homogeneity (Shapiro-Wilk test and Levene test), numbers of insects stuck in the glue were compared using one-way ANOVA $(\mathrm{P}<0.05)$, and in case of significance means were separated using Tukey test $(\mathrm{P}<0.05)$. The percentages of damaged fruits were compared using the non-parametric analysis of Kruskal-Wallis, as the assumption of homogeneity was not met (Levene test); the means were then separated using Mann-Whitney $U$-test $(\mathrm{P}<0.05)$.

The $_{\text {SPSS }}{ }^{\circledR}$ statistical package for Windows (version17.0; SPSS ${ }^{\circledR}$ Inc., Chicago, IL, USA) was used for the statistical analyses.

\section{Results}

\subsection{Field trials}

152 In the orchards under investigation, the European earwig $F$. auricularia was the predominant 153 species, while just a few specimens of maritime earwig Anisolabis maritima (Bonelli)

154 (Anisolabidae) and of short-winged earwig Apterygida media (Hagenbach) were recorded. Earwig 155 populations were mainly composed of nymphs until mid-June, and then adults increased. Seasonal 
abundance of earwigs was variable in the three orchards. In orchard 1, in both years earwig nymphs were first observed at the end of April and nymph abundance peaked in mid-June. Adults appeared in mid-June in 2010 and at the end of May in 2011, and their abundance reached 83.7 adults trap ${ }^{-1}$ on July 8 in 2010, and 60.6 adults trap ${ }^{-1}$ on June 20 in 2011 (Figs. 1, 2). In orchard 2 in 2010, earwigs were first observed at the end of April. Nymph abundance peaked on June 3 with 266.3 nymphs trap ${ }^{-1}$, and adult abundance peaked on June 24 with 201.5 adults trap ${ }^{-1}$ (Fig. 1). In orchard 3 in 2011, earwigs were found starting from early May. Nymph abundance peaked on May 16 with 17.8 nymphs trap $^{-1}$, and adult abundance peaked on June 20 with 13.8 adults trap ${ }^{-1}$ (Fig. 2). [Figures 1 and 2 near here]

Earwig captures on Vebicolla $^{\circledR}$ and Rampastop ${ }^{\circledR}$ glues were very low. Mean number of earwigs stuck in the glue was higher than 2 only on Rampastop ${ }^{\circledR}$ on June 18 and on Vebicolla ${ }^{\circledR}$ on July 1 in orchard 2 in 2010, and on Rampastop ${ }^{\circledR}$ on June 6 in orchard 3 in 2011. The number of earwigs captured in the cardboard traps placed above the glues in 2011 was also very low. Maximum densities of earwigs trap $^{-1}$ were 2.8 for Rampastop ${ }^{\circledR}$ and 13.6 for Vebicolla ${ }^{\circledR}$ in orchard 1 , and 0.2 for Rampastop ${ }^{\circledR}$ and 4.6 for Vebicolla ${ }^{\circledR}$ in orchard 3 (Table 1). The number of earwigs captured in the cardboard traps was significantly higher in control trees than in treated trees on May 31 (Kruskal-Wallis analysis: $\mathrm{df}=2$, chi-square $=10.789, \mathrm{P}=0.005$ ), on June 6 (Kruskal-Wallis analysis: $\mathrm{df}=2$, chi-square $=12.133, \mathrm{P}=0.002$ ), and on June 13 (Kruskal-Wallis analysis: $\mathrm{df}=2$, chi-square $=10.556, \mathrm{P}=0.005)$ in orchard 1. In orchard 3 , the number of specimens captured on control trees was significantly greater than that recorded on trees with glues on May 31 (KruskalWallis analysis: $\mathrm{df}=2$, chi-square $=11.0765, \mathrm{P}=0.004$ ), and on June 6 (Kruskal-Wallis analysis: $\mathrm{df}=2$, chi-square $=11.024, \mathrm{P}=0.004)$. [Table 1 near here $]$ orchard 2, respectively, while in 2011 2,039 and 2,981 fruits were checked in orchard 1 and orchard In order to assess fruit damage, in 2010 8,419 and 16,951 fruits were checked in orchard 1 and 3, respectively. Significant differences were found between treatments, years and blocks (glue:

81 Wald $\chi^{2}=360.755, \mathrm{P}<0.01$; year: Wald $\chi^{2}=4.195, \mathrm{P}=0.041$; block: Wald $\chi^{2}=485.845, \mathrm{P}<0.01$; 
182 glue*year: Wald $\chi^{2}=63.658, \mathrm{P}<0.01$ ) (Fig. 3). Percentage of fruit damage was significantly higher

183 in the control than in treatments in both years. Moreover, both glues were significantly more

184 effective in damage reduction in 2011 than in 2010, and overall Rampastop ${ }^{\circledR}$ proved to be the most 185 efficient control method. [Figure 3 near here]

\subsection{Laboratory trials}

187

At the first inspection 24 hours after earwig introduction, percentages of individuals trapped on the glue were $15 \%$ on Rampastop ${ }^{\circledR}$ and $5 \%$ on Vebicolla ${ }^{\circledR}$, with no significant differences between treatments (ANOVA: $\mathrm{df}=1,6, \mathrm{~F}=0.857, \mathrm{P}=0.390$ ). At the second inspection 48 hours after insect introduction, the rate of individuals glued on Rampastop ${ }^{\circledR}$ increased to $50 \%$, whereas the percentage of individuals glued on Vebicolla ${ }^{\circledR}$ did not change (ANOVA: $\mathrm{df}=1,6, \mathrm{~F}=13.714, \mathrm{P}=0.010$ ). Percentage of damaged fruits was null for Rampastop ${ }^{\circledR}$ and Vebicolla ${ }^{\circledR}$, while it reached $75 \%$ in the control (Kruskal-Wallis analysis: $\mathrm{df}=2$, chi-square $=7.333, \mathrm{P}=0.026)$ (Table 2$).$ In the control all individuals were alive at both inspections. [Table 2 near here]

\section{Discussion}

Surveys by means of cardboard traps demonstrated that F. auricularia is the predominant earwig species in apricot orchards in Piedmont and represents a serious treat for fruit farming. Forficula auricularia is a univoltine species even though some females can produce two broods, as was observed in southern France and Belgium (Guillet et al. 2000, Moerkens et al. 2009). In this case, a small number of females produce a second clutch in early summer of the same year, and during summer adults of the first brood coexist with nymphs of the second brood. Our sampling data lead us to suppose that the population living in the study area exhibits only one brood, since the appearance of adults corresponded with a progressive decrease of juvenile stages at the end of spring. Nonetheless, further sampling throughout the whole season is required to confirm this hypothesis. 
In the present study, earwig density was highly variable throughout years and orchards. In 2010, the great difference in population levels in orchards 1 and 2 could be explained by the presence of two different cultivars in these orchards. 'Tonda di Costigliole' in orchard 2 is an old, local variety characterised by late yield and by fruits with a very intense aroma and a juicy pulp (Valentini et al. 2004). As reported by local growers, these qualities could make it more luring for F. auricularia,

212 justifying the high number of insects collected on the cardboard traps placed on the trunks of these 213 plants. On the other hand, different earwig abundance recorded in 2011 could be due to the different 214 altitudinal location of the two orchards, with orchard 1 characterised by a lower temperature range 215 (data not shown) and thus probably more favourable to earwig population. The relationship between F. auricularia biological cycle and temperature has already been highlighted, and allowed the 217 development of day degree models to predict the phenology of earwig populations (Helsen et al. 218 1998, Moerkens et al. 2011).

219 The application of arboreal glues on tree trunk proved to be effective for earwig control and determined a significant reduction in fruit damage. The very low number of $F$. auricularia captured 221 in the cardboard traps placed above the glues compared with captures obtained on control trees 222 proved the effectiveness of glues as physical barriers to prevent earwigs from climbing up the 223 trunks and reaching ripening fruits. In particular, Rampastop ${ }^{\circledR}$ was the most successful one on trees 224 with a very rough and cracked bark (orchard 3), since in this case the plastic tape spread with 225 Vebicolla ${ }^{\circledR}$ could not completely adhere to the trunk. These positive results were also confirmed by 226 laboratory trials.

227 The positive effect of the glues in reducing fruit damage was notably evident in 2011, but less in 228 2010. In 2010, 'Tonda di Costigliole' apricot trees (orchard 2) showed a very low percentage of 229 damaged fruits also on untreated plants, despite a very high earwig population density. It is 230 probable that the fruits are very luring for $F$. auricularia, attracting a huge number of insects on the 231 trunks, but maybe the texture is not appreciated. These results demonstrate also that a high earwig 
population density in the orchard does not always correspond to a high rate of fruit damage, and that 233 different cultivars can show different suitability for $F$. auricularia.

234 Despite the high number of earwigs captured in the cardboard traps on control trees, the number of earwigs trapped on the glues was always very low regardless of apricot cultivar. Moreover, no other insects were observed trapped on the glues, except for some flies. This suggests that glues could have a repellent action against insects, even if this was only partially confirmed by results obtained in laboratory trials, where more than $40 \%$ of the individuals were stuck on Rampastop ${ }^{\circledR}$. However, laboratory trials imply artificial conditions and little space for earwigs to move in, factors that might have partially affected the insects' behaviour.

The use of glues should be harmless to the agro-ecosystem and safe for beneficial insects. However, further research is needed to ascertain the impact of glues on beneficial arthropods. Previous studies demonstrated that glue rings could also exclude ants from the trees, in particular aphid-tending ants. As a consequence, higher predator densities and lower aphid densities can be observed (Miñarro et al. 2010, Stutz \& Entling 2011), while in other cases aphid abundance increases due to the concurrent exclusion of earwigs (Piñol et al. 2009). The present study was not aimed at assessing the effect of glues on ant populations, and ant abundance in sampled orchards was unremarkable.

248 Nonetheless, during field surveys no ants were recorded on the glues. The possible increase of 249 aphid populations due to earwig exclusion, as observed in citrus and apple orchards (Mueller et al. 1988, Nicholas et al. 2005, Romeu-Dalmau et al. 2012), is worthy of further investigations. Anyway, in all the cases in which earwig populations are so high to cause significant damage to the fruits, and other control strategies are not advisable (e.g., chemical treatments close to harvest time), the use of arboreal glues offers more pros than cons.

254 The presence, even if small, of earwigs in cardboard traps above the glues suggests that the 255 European earwig adults can somehow bypass the glue. According to the literature, F. auricularia rarely flies even though it has completely developed wings (Fontana et al. 2002). Empirical remarks indicated that a small number of individuals was able to reach the canopy of isolated apricot trees 
with a very large band of Rampastop ${ }^{\circledR}$ glue on the trunk (authors' unpublished data), suggesting that earwigs might eventually move by flying, when no other possibility is available. In the presence of 260 large earwig populations, the application of glue on the trunk might therefore not be sufficient to 261 completely prevent fruit damage and should be complemented with other techniques. According to 262 some studies, earwig population density can be reduced with proper orchard management practices 263 such as soil tillage, which negatively affects earwigs during their nesting phase (Moerkens et al. 264 2011, 2012, Sharley et al. 2008). Combining soil tillage at earwig nesting phase and application of 265 glue barriers on tree trunk at time of earwig migration to the tree could help in reducing fruit 266 damage by earwigs without the use of insecticides, thus avoiding the negative side-effects spray 267 applications might have on beneficial insects present in the orchard, such as bees and hoverflies.

\section{Acknowledgments}

270 The authors would like to thank the fruit growers Cristian Occelli, Felice Gozzarino, and Giovanni

271 Bonetto for permission to conduct field research in their orchards. We thank Prof. Dario Sacco 272 (DISAFA, University of Torino) for his support in statistical analyses. This research was supported 273 by grants from Regione Piemonte - Assessorato Agricoltura.

References

Alston DG, Tebeau A. 2011. European Earwig (Forficula auricularia). UTAH Pests Fact Sheets

ENT-145-1. (http://extension.usu.edu/files/publications/factsheet/earwig-tf.pdf) (Accessed May 18, 278 2015).

Asteggiano L, Vittone G. 2013. Albicocche e nettarine, come contenere i danni delle forficule. Frutticoltura 6:60-61. 
Burnip GM, Daly JM, Hackett JK, Suckling DM. 2002.European earwig phenology and effect of understorey management on population estimation. N. Z. Plant Protect. 55:390-395.

Caroli L, Perri F, Santini L. 1993. Defoliazioni da Forficula auricularia L. su agrumi e drupacee. Inftore Fitopatol. 43:19-23.

Dib H, Simon S, Sauphanor B, Capowiez Y. 2010. The role of natural enemies on the population dynamics of the rosy apple aphid, Dysaphis plantaginea Passerini (Hemiptera: Aphididae) in organic apple orchards in south-eastern France. Biological Control 55:97-109.

Dib H, Jamont M, Sauphanor B, Capowiez Y. 2011. Predation potency and intraguild interactions between generalist (Forficula auricularia) and specialist (Episyrphus balteatus) predators of the rosy apple aphid (Dysaphis plantaginea). Biological Control 59:90-97.

Flint ML. 2012. Earwigs. University of California Statewide, Integrated Pest Management Program, Agriculture and Natural Resources. Pest Notes, Publication 74102 (http://www.ipm.ucdavis.edu/PDF/PESTNOTES/pnearwigs.pdf) (Accessed May 13, 2015).

Fontana P, Buzzetti FM, Cogo A, Odé B. 2002. Guida al riconoscimento e allo studio di cavallette, grilli, mantidi e insetti affini del Veneto: Blattaria, Mantodea, Isoptera, Orthoptera, Phasmatodea, Dermaptera, Embiidina. Vicenza (Italy): Museo Naturalistico Archeologico di Vicenza.

305 Glenn DM. 1977. Predation of codling moth eggs, Cydia pomonella, the predators responsible and their alternative prey. J. Appl. Ecology 14:445-456. 
308 Gobin B, Moerkens R, Leirs H, Peusens G. 2008. Earwigs in fruit orchards: phenology predicts

309 predation effect and vulnerability to side-effects of orchard management. IOBC/WPRS Bull. 35:3531039.

312 Guillet S, Guiller A, Deunff J, Vancassel M. 2000. Analysis of a contact zone in the Forficula 313 auricularia L. (Dermaptera: Forficulidae) species complex in the Pyrenean Mountains. Heredity $314 \quad 85: 444-449$.

Helsen H, Vaal F, Blommers L. 1998. Phenology of the common earwig Forficula auricularia L. (Dermapetra: Foficulidae) in an apple orchard. Int. J. Pest Manag. 44:75-79.

Huth C, Schirra KJ, Seitz A, Louis F. 2011. A beneficial species becomes a pest-the common earwig Forficula auricularia (Linnaeus 1758). IOBC/WPRS Bull. 67:249-256.

Kallsen C. 2006. Earwigs Flying Under the Radar of Many Citrus Pest Control Advisors. Topics in Subtropics Newsletter 4:3-4.

Logan DP, Maher BJ, Connolly P. 2011. Increased numbers of earwigs (Forficula auricularia) in kiwifruit orchards are associated with fewer broad-spectrum sprays. N Z Plant Prot 64:49-54.

Logan DP, Maher BJ, Connolly PG, Pettigrew MJ. 2007. Effect of cardboard shelter traps on predation of diaspidid scale insects by European earwigs, Forficula auricularia, in kiwifruit. N. Z. Plant Protect. 60:241-248. earwig: Response to impregnated shelters. Crop Prot. 65:71-76. 
335 Maher BJ, Logan DP. 2007. European earwigs, Forficula auricularia, and predation of scale insects 336 in organic and conventionally managed kiwifruit. N. Z. Plant Protect. 60:249-253.

Miñarro M, Fernández-Mata G, Medina P. 2010. Role of ants in structuring the aphid community on apple. Ecological Entomology 35:206-215.

Moerkens R, Leirs H, Peusens G, Gobin B. 2009. Are populations of European earwig, Forficula auricularia, density dependent? Entomol. Exp. Appl. 130:198-206.

Moerkens R, Gobin B, Peusens G, Helsent H, Hilton R, Dib H, Suckling DM, Leirs H. 2011.

Optimizing biocontrol using phenological day degree models: the European earwig in pipfruit orchards. Agric. Forest. Entomol. 13:301-312.

Moerkens R, Leirs H, Peusens G, Belien T, Gobin B. 2012. Natural and human causes of earwig mortality during winter: temperature, parasitoids and soil tillage. J. Appl. Entomol. 136:490-500.

Mueller TF, Blommers LHM, Mols PJM. 1988. Earwig (Forficula auricularia) predation on the woolly apple aphid, Eriosoma lanigerum. Entomol. Exp. Appl. 47:145-152.

Nicholas AH, Spooner-Hart RN, Vickers RA. 2005. Abundance and natural control of the woolly aphid Eriosoma lanigerum in an Australian apple orchard IPM program. BioControl 50:271-291. 
360 Piñol J, Espadaler X, Cañellas N, Pérez N. 2009. Effects of the concurrent exclusion of ants and 361 earwigs on aphid abundance in an organic citrus grove. BioControl 54:515-527.

363 Pollini A. 2010. La forbicetta è comunissima e danneggia talvolta i frutti prossimi alla raccolta. Inf. 364 Agrar. 10:31.

366 Romeu-Dalmau C, Piñol J, Espadaler X. 2012. Friend or foe? The role of earwigs in a 367 Mediterranean organic citrus orchard. Biological Control 63:143-149.

369 Santini L, Caroli L. 1992. Danni ai fruttiferi da forficola comune (Forficula auricularia L.). Inftore 370 Fitopatol. 42:35-38.

372 Sauphanor B, Lenfant C, Brunet E, Faivre D’Arcier F, Lyoussoufi A, Rieux R. 1994. Regulation 373 des population de psylle de poirier, Cacopsylla pyri (L.) par un predateur generaliste, Forficula 374 auricularia L. IOBC/WPRS Bull. 17 (2):125-131.

Sharley DJ, Hoffmann AA, Thomson LJ. 2008. The effects of soil tillage on beneficial invertebrates within the vineyard. Agric. Forest Entomol. 10:233-243.

Stutz S, Entling MH. 2011. Effects of the landscape context on aphid-ant-predator interactions on 380 cherry trees. Biological Control 57:37-43.

382 Suckling DM, Burnip GM, Hackett J, Daly JC. 2006. Frass sampling and baiting indicate European 383 earwig (Forficula auricularia) foraging in orchards. J. Appl. Entomol. 130:263-267. 
385 Valentini N, Aigotti R, Botta R, Zeppa G, Mellano MG. 2004. Tonda di Costigliole: dal Piemonte 386 l'albicocca più tardiva. Rivista di frutticoltura e di ortofloricoltura 66 (9):60-63. 
390 Table 1 - Total number and percentage of adults of European earwigs collected in corrugated 391 cardboard traps placed on the trunks above Rampastop ${ }^{\circledR}$ and Vebicolla ${ }^{\circledR}$ glues and on control trees 392 in two apricot orchards in 2011. In the rows, means per cardboard trap followed by different letters 393 are significantly different (Mann-Whitney $U$-test, $\mathrm{P}<0.05$ ).

Table 2 - Percentage of damaged fruits and insects stuck on Rampastop ${ }^{\circledR}$ and Vebicolla ${ }^{\circledR}$ glues in laboratory trials. In the columns, means followed by different letters are significantly different (damaged fruit, Mann-Whitney $U$-test, $\mathrm{P}<0.05$; insects on glue, Tukey test, $\mathrm{P}<0.05$ ).

\section{Figure captions}

Fig. 1 - Nymphs and adults Forficula auricularia (mean number \pm SE) collected in corrugated cardboard traps (control trees) in apricot orchards 1 (a) and 2 (b) in 2010.

Fig. 2 - Nymphs and adults Forficula auricularia (mean number \pm SE) collected in corrugated cardboard traps (control trees) in apricot orchards 1(a) and 3 (b) in 2011.

Fig. 3 - Logit of apricots damaged by European earwig at harvest in the orchards surveyed in 2010 408 and 2011, predicted by Generalized Linear Model (glue: Wald $\chi^{2}=360.755, \mathrm{P}<0.01$; year: Wald $\chi^{2}$ $409=4.195, \mathrm{P}=0.041$; glue*year: Wald $\left.\chi^{2}=63.658, \mathrm{P}<0.01\right)$. Data marked by different letters are 410 significantly different (Bonferroni test, $\mathrm{P}<0.05)$. 


\begin{tabular}{lcccccc}
\hline \multirow{2}{*}{ Date } & \multicolumn{2}{l}{$\begin{array}{l}\text { Corrugated cardboard on } \\
\text { untreated plants }\end{array}$} & \multicolumn{3}{l}{ Corrugated cardboard placed above } \\
\cline { 3 - 7 } & Total \pm SE & $\%$ adults & Total \pm SE & $\%$ adults & Total \pm SE & $\%$ adults \\
\hline Orchard 1 & & & & & & \\
31May & $13.4 \pm 3.4 \mathrm{a}$ & 1.5 & $0.2 \pm 0.2 \mathrm{~b}$ & 100.0 & $1.2 \pm 0.6 \mathrm{~b}$ & 16.7 \\
06June & $44.0 \pm 1.7 \mathrm{a}$ & 1.8 & $0.0 \pm 0.0 \mathrm{~b}$ & 0.0 & $3.8 \pm 1.9 \mathrm{c}$ & 42.1 \\
13June & $70.8 \pm 1.9 \mathrm{a}$ & 6.5 & $0.4 \pm 0.4 \mathrm{~b}$ & 100.0 & $4.0 \pm 3.8 \mathrm{~b}$ & 85.0 \\
20June & $68.8 \pm 11.6 \mathrm{a}$ & 88.1 & $2.8 \pm 1.4 \mathrm{a}$ & 100.0 & $13.6 \pm 8.4 \mathrm{a}$ & 100.0 \\
Orchard 3 & & & & & & \\
31May & $6.8 \pm 1.9 \mathrm{a}$ & 41.2 & $0.2 \pm 0.2 \mathrm{~b}$ & 100.0 & $0.2 \pm 0.2 \mathrm{~b}$ & 100.0 \\
06June & $8.8 \pm 1.7 \mathrm{a}$ & 95.4 & $0.0 \pm 0.0 \mathrm{~b}$ & 0.0 & $0.7 \pm 0.3 \mathrm{~b}$ & 97.8 \\
13June & $2.0 \pm 1.9 \mathrm{a}$ & 100.0 & $0.0 \pm 0.0 \mathrm{a}$ & 0.0 & $0.6 \pm 0.4 \mathrm{a}$ & 100.0 \\
20June & $13.8 \pm 11.6 \mathrm{a}$ & 100.0 & $0.2 \pm 0.2 \mathrm{a}$ & 100.0 & $4.6 \pm 2.5 \mathrm{a}$ & 100.0 \\
\hline
\end{tabular}

413 Saladini et al., Table 1.

414 
415

\begin{tabular}{lcccc}
\hline Treatments & \multicolumn{2}{c}{ Insects on glue $\%$ D $\mathrm{SE}$} & \multicolumn{2}{c}{ Damaged fruits $(\%) \pm \mathrm{SE}$} \\
\cline { 2 - 5 } & After $24 \mathrm{~h}$ & After $48 \mathrm{~h}$ & After $24 \mathrm{~h}$ & After $48 \mathrm{~h}$ \\
\hline Rampastop & $15 \pm 0.5 \mathrm{a}$ & $50 \pm 0.5 \mathrm{a}$ & $0 \mathrm{a}$ & $0 \mathrm{~b}$ \\
Vebicolla & $5 \pm 0.2 \mathrm{a}$ & $5 \pm 0.2 \mathrm{~b}$ & $0 \mathrm{a}$ & $0 \mathrm{~b}$ \\
Control & - & - & $0 \mathrm{a}$ & $75 \pm 0.2 \mathrm{a}$ \\
\hline
\end{tabular}

416 Saladini et al., Table 2. 

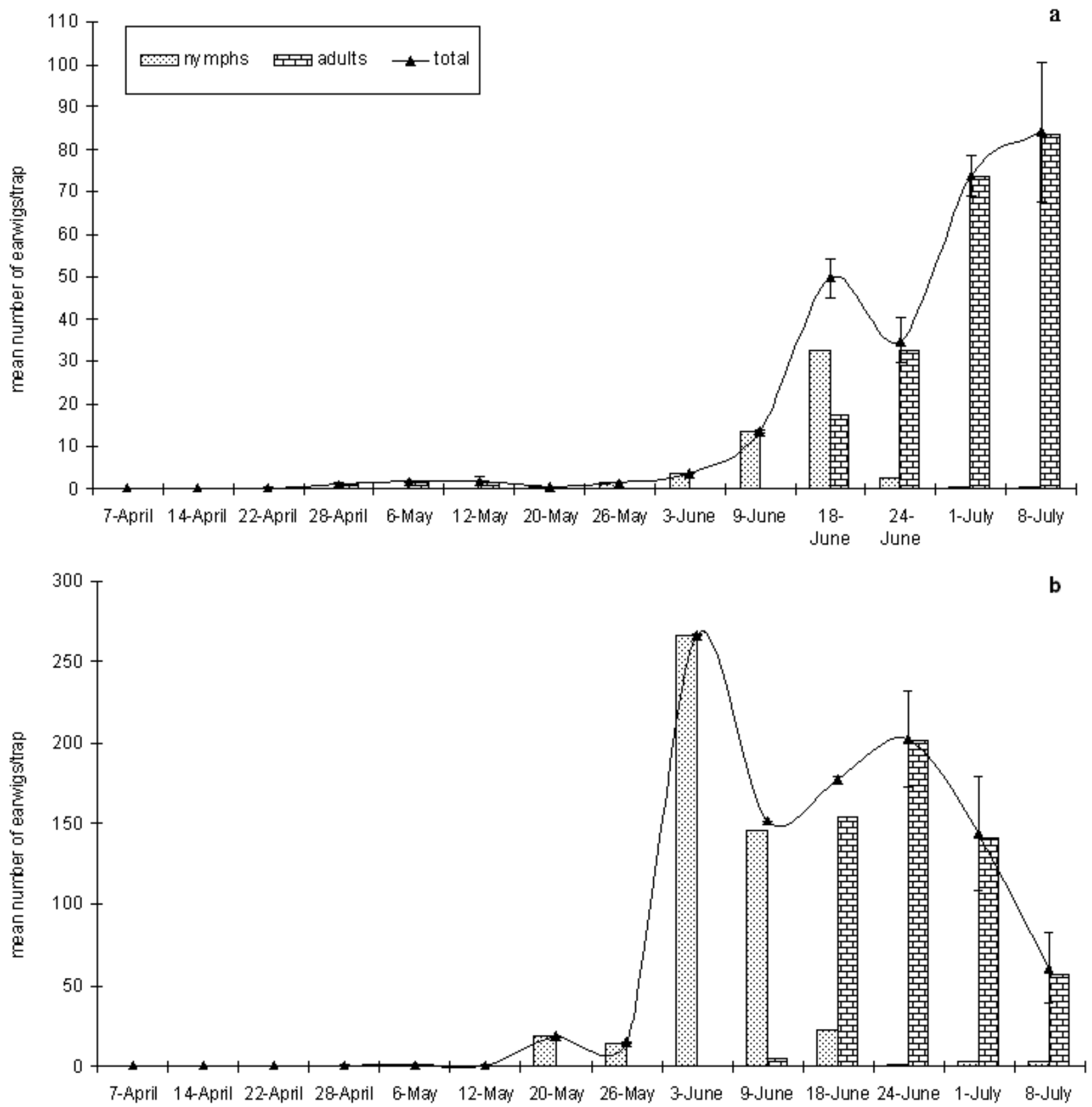

418 Saladini et al., Figure 1. 

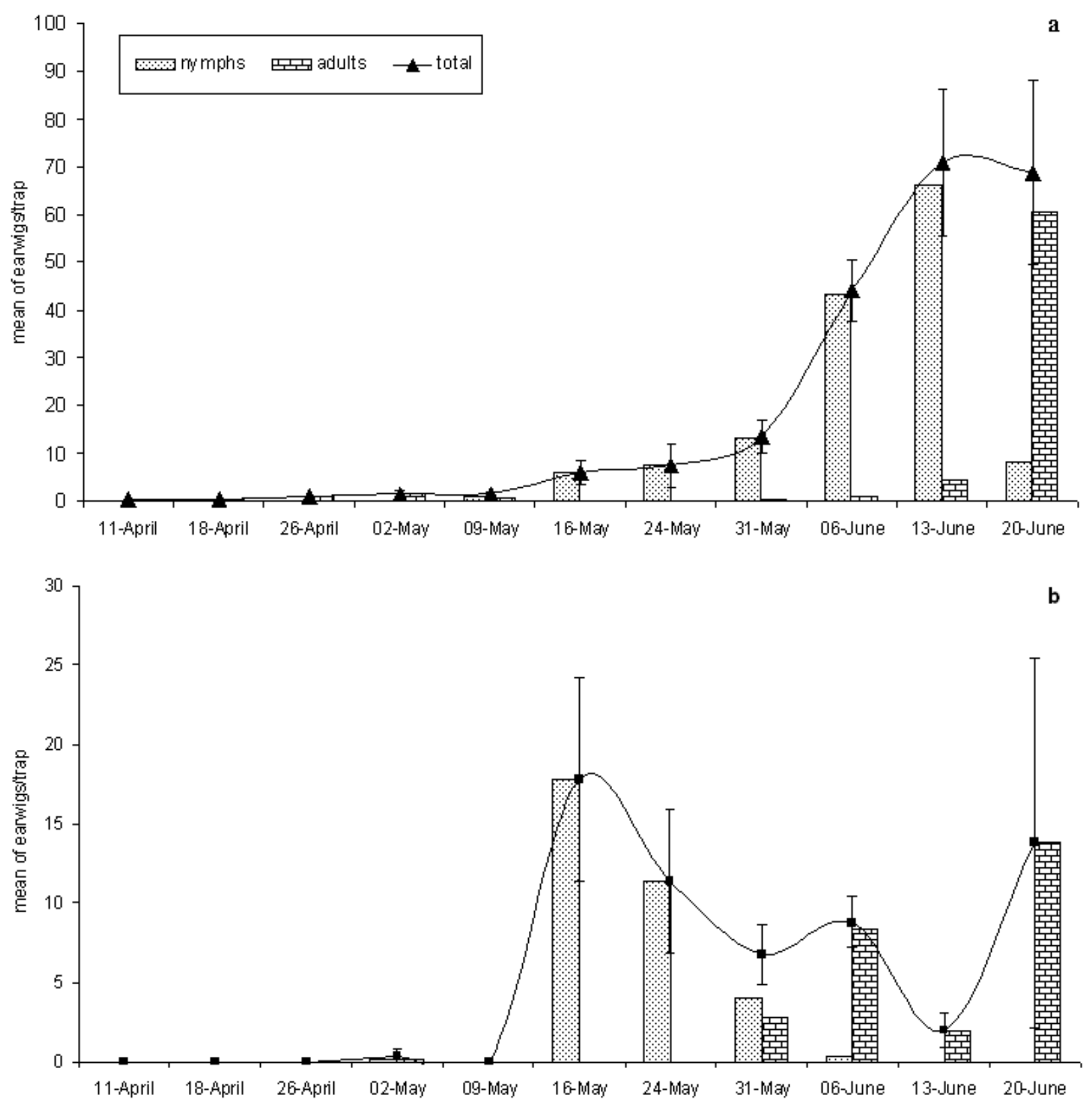

421 Saladini et al., Figure 2. 


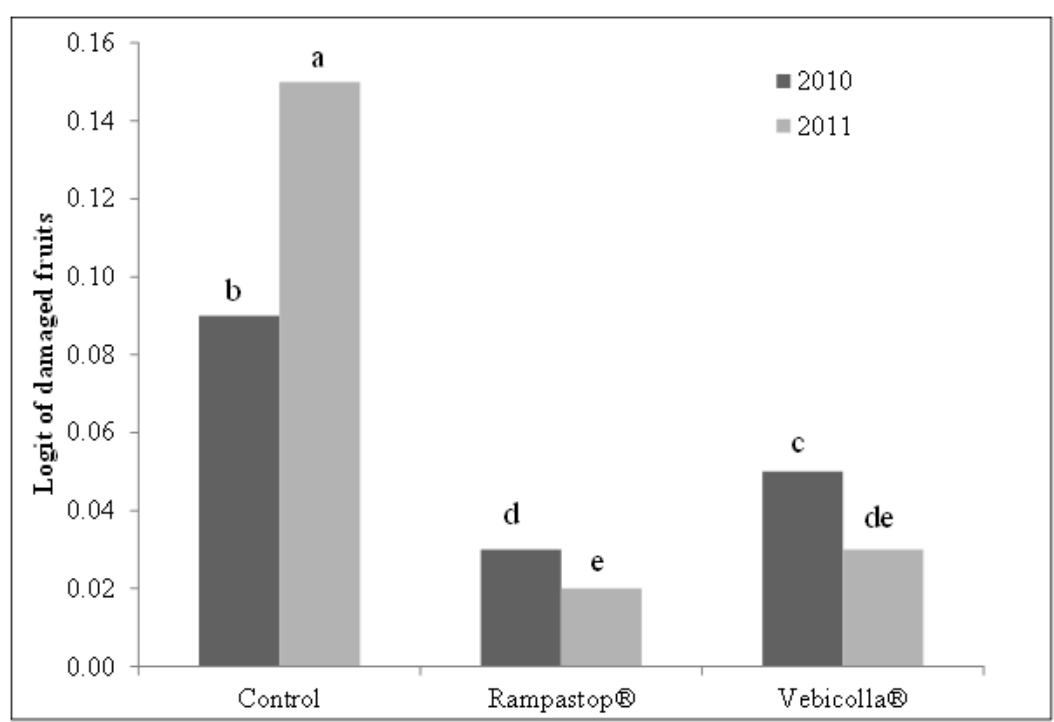

423

424 Saladini et al., Figure 3.

425 